\title{
Effect of long-term glucocorticoid treatment on oestradiol-induced proliferation in the uterus of ovariectomized rats
}

\author{
A G Gunin \\ Department of Histology, Medical Institute of Chuvash State University, 15 Moscowski Avenue, Cheboksary, 428015, Russia
}

\begin{abstract}
The aim of this study was to examine the effect of long-term treatment with glucocorticoids on the uterine response to oestradiol. Ovariectomized rats were treated with crystal triamcinolone acetonide $(0 \cdot 1 \mathrm{mg} / 100 \mathrm{~g}$, i.m. $)$ or saline $(0 \cdot 1 \mathrm{ml} / 100 \mathrm{~g}$ i.m.) for 29 days. Over this period five injections were administered, one per week. On the second day after the last triamcinolone injection, rats were treated with a single injection of oestradiol dipropionate (5 $\mu \mathrm{g} / 100 \mathrm{~g}$, s.c.) or vehicle (olive oil, $0 \cdot 1 \mathrm{ml} / 100 \mathrm{~g}$, s.c.). The effects of oestradiol in the uterus were determined by measuring mitotic index, bromodeoxyuridine (BrdU)labelling index (BrdU was injected $2 \mathrm{~h}$ before the rats were killed; $2 \mathrm{mg} / 100 \mathrm{~g}$, i.p.), and proliferating cell nuclear antigen (PCNA)-labelling index 24, 36 and $48 \mathrm{~h}$
\end{abstract}

after the injection of oestradiol or vehicle. Long-term treatment with glucocorticoids resulted in dissimilar changes in oestradiol-induced proliferation in epithelial and connective-tissue (stroma) components of the uterus. In luminal and glandular epithelia, there was an initial reduction in proliferation at $24 \mathrm{~h}$, followed by an increase at $36 \mathrm{~h}$ and a further reduction at $48 \mathrm{~h}$ after the oestradiol injection. In stromal cells of the endometrium, triamcinolone treatment caused a large constant increase in oestradiol-induced proliferation throughout the experiment. The glucocorticoid treatment had no effect on the parameters without oestradiol administration.

Journal of Endocrinology (1998) 157, 481-488

\section{Introduction}

Strong activation of proliferative activity is the most important physiological effect of oestrogen hormones in the uterus. Oestrogens can also lead to the formation of endometrial carcinoma and other oestrogen-dependent diseases (Nagaoka et al. 1993). Therefore this powerful action of oestrogens must be strongly controlled. Many different biologically active substances are known to regulate oestrogen action on target tissues, including glucocorticoid hormones.

It is known that glucocorticoids can affect uterine response to oestrogen steroids. Almost all investigations of this process have clearly shown that glucocorticoids greatly diminish oestrogen-stimulated synthesis of DNA and activation of proliferation in the uterus (Tchernitchin et al. 1975, Campbell 1978, Stewart et al. 1983, Bigsby 1993). Moreover, the content of various factors and activity of various processes, such as ornithine decarboxylase activity (Stewart et al. 1983), number of oestrogen receptors (Lisk \& Reuter 1976, Markaverich et al. 1981, Atkinson \& Adams 1988, Rabin et al. 1990, Zamorano et al. 1992), blood flow (Monheit \& Resnik 1981), protein synthesis (Lippe \& Szego 1965, Sullivan et al. 1983), prostaglandin synthesis (Dey et al. 1982, Pakrasi et al. 1983, Jacobs et al.
1994), c-fos mRNA (Kirkland et al. 1992), insulin-like growth factor-I mRNA (Sahlin 1995), associated or mediated oestradiol-induced increase in mitotic activity in the uterus, are also inhibited by glucocorticoids. However, it should be noted that all the researches so far have only demonstrated glucocorticoid action after acute or shortterm treatment, and there are no data on long-term effects of glucocorticoids on oestradiol-induced processes in the uterus.

The number of glucocorticoid receptors in tissues other than the uterus has been shown to decrease under conditions of chronic stress or after prolonged glucocorticoid administration (Pottinger 1990, Schmidt \& Meyer 1994, Herman et al. 1995, Sapolsky 1996). In addition, long-term glucocorticoid treatment can lead to a decrease in prolactin concentration (Piroli et al. 1993, Taylor et al. 1995), which has been shown to result in decreased oestradiol-induced effects in the uterus (Gunin 1996). Therefore it can be suggested that uterine response to oestradiol under long-term treatment may differ from that after acute or short-term treatment with glucocorticoids. Therefore the aim of this work was to examine the effect of long-term treatment with glucocorticoids on the activity of oestradiol-stimulated proliferation in the uterus. 


\section{Materials and Methods}

\section{Animals}

All procedures were performed in accordance with the Guidelines on the Handling and Training of Laboratory Animals published by the Universities Federation for Animal Welfare.

Female mature outbred white rats were maintained under constant conditions with free access to water and food. All the rats were ovariectomized under anaesthesia with ketamine and droperidol $(7 \mathrm{mg} / \mathrm{rat} ; 0 \cdot 1 \mathrm{mg} / \mathrm{rat}$, i.m.; Gedeon Richter, Budapest, Hungary).

\section{Treatment protocol}

From the fourth day after ovariectomy, rats received injections of crystal triamcinolone acetonide (single dose, $0 \cdot 1 \mathrm{mg} / 100 \mathrm{~g}$, i.m.; KENALOG; Bristol-Myers Squibb $\mathrm{GmbH}$, Munich, Germany) or vehicle (saline; $0.1 \mathrm{ml} /$ $100 \mathrm{~g}, \mathrm{i} . \mathrm{m}$.) once a week for 29 days, five injections in all. This crystal form of triamcinolone acetonide produces a prolonged (not less than 1 week) effect after i.m. injection (Mikhail et al. 1977, Lypko et al. 1983).

On the second day after the last triamcinolone or vehicle administration (33 days after ovariectomy), rats were treated with a single injection of either oestradiol dipropionate (5 $\mu \mathrm{g} / 100 \mathrm{~g}$, s.c.; Minmedprom, RostovDon, Russia) or vehicle (olive oil; $0 \cdot 1 \mathrm{ml} / 100$ g, s.c.).

There were seven rats per oestradiol-treated group, and five animals per untreated group. At $2 \mathrm{~h}$ before they were killed, all the rats were injected i.p. with bromodeoxyuridine (BrdU; $2 \mathrm{mg} / 100 \mathrm{~g}$; Sigma Chemical Co., St Louis, MO, USA) dissolved in saline.

Observations were made 24, 36 and 48 h after oestradiol or olive oil injection.

\section{Methods}

The middle segment of both uterine horns, the adrenal glands and the thymus were removed under deep ether anaesthesia. The animals were then killed by exsanguination.

Animals were weighed on the day of ovariectomy and just before their death. Adrenal glands and thymus were also weighed immediately after their removal. This procedure was used to control general glucocorticoid effects.

Uteri were immediately placed in fixing fluids. Part of the tissue from each animal was fixed in Carnoy's fluid ( $2 \mathrm{~h}$ at room temperature) and part in Bouin's fluid ( $8 \mathrm{~h}$ at room temperature) (Lacey 1989). All material was then dehydrated and embedded in paraffin. Transverse sections were cut at $5-7 \mu \mathrm{m}$.

Effects of oestradiol in the uterus were assessed using the mitotic index, the BrdU-labelling index and the proliferating cell nuclear antigen (PCNA)-labelling index.

\section{Immunohistochemistry}

BrdU and PCNA were detected using immunohistochemical staining. For determination of PCNA, sections fixed in Bouin's fluid were used, and, for determination of BrdU, sections fixed in Carnoy's fluid were used. Sections were hydrated. For detection of BrdU, slides were put in $2 \mathrm{M} \mathrm{HCl}$ for $15 \mathrm{~min}$ at $60{ }^{\circ} \mathrm{C}$ to denature DNA. The sections were then rinsed $(3 \times 10 \mathrm{~min})$ in Tris-buffered

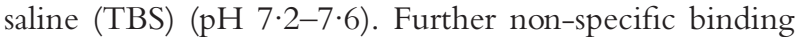
was blocked with 5\% normal goat serum in TBS for $1 \mathrm{~h}$. For PCNA detection, tissues were incubated for $2 \mathrm{~h}$ with primary anti-PCNA mouse monoclonal antibody (Santa Cruz Biotechnology Inc., Santa Cruz, CA, USA) diluted $1: 50$ in TBS with $1 \%$ normal goat serum and $0 \cdot 1 \%$ Triton $\mathrm{X}-100$. For BrdU detection, sections were incubated overnight with primary anti-BrdU mouse monoclonal antibody (Sigma Chemical Co.) diluted 1:50 in TBS with $1 \%$ normal goat serum and $0 \cdot 1 \%$ Triton X-100. After being rinsed in TBS $(3 \times 5 \mathrm{~min})$, sections were incubated for $1 \mathrm{~h}$ with secondary goat anti-mouse immunoglobulin $\mathrm{G}$ antibody conjugated with alkaline phosphatase (Jackson ImmunoResearch Laboratories Inc., West Grove, PA, USA) diluted 1:100 in TBS with $0 \cdot 1 \%$ Triton $\mathrm{X}-100$; the sections were then rinsed again in TBS $(3 \times 5 \mathrm{~min})$. Alkaline phosphatase activity was revealed through the use of naphthol AS-BI-phosphate and new fuchsin as chromogens. Slides were then prepared for light microscopy. All procedures were performed at room temperature. Control sections were stained in a similar manner, except that the primary antibody was replaced with normal goat serum. In both cases, positive staining by primary antibody was indicated by a red precipitate localized in the nuclei.

\section{Determination of mitotic and labelling indices}

Mitotic index was determined in uterine sections fixed in Carnoy's fluid and stained with iron haematoxylin. All procedures for determination of mitotic and labelling indices were performed under a light microscope. All results were expressed as percentage of dividing or labelled cells.

For determination of mitotic, PCNA- and BrdUlabelling indices for the luminal and glandular epithelia, all cells of the luminal epithelium and the epithelium of the endometrial glands (separately) in whole transverse section were counted, and dividing or PCNA- or BrdU-labelled cells were also counted. Not less than 3000 cells were viewed per rat. Mitotic or labelling indices were then calculated by dividing the number of mitotic or labelled cells into the total number of cells counted.

The mitotic index for endometrial stromal cells was calculated as follows. Whole transverse sections were viewed and all dividing cells were counted. The total number of stromal cells per section was then calculated by counting the number of stromal cells per field of view of 
Table 1 Effect of long-term treatment with triamcinolone on body weight, the weight of adrenal glands and thymus of ovariectomized rats. Values are mean \pm S.E.M.

\begin{tabular}{|c|c|c|c|}
\hline & Treatment & Olive oil $(n=5)$ & Oestradiol $(n=7)$ \\
\hline \multirow[t]{2}{*}{ Body weight of rat $(\mathrm{g})^{\mathrm{a}}$} & Saline & $221 \cdot 1 \pm 11 \cdot 4$ & $217 \cdot 3 \pm 6 \cdot 5$ \\
\hline & Triamcinolone & $158 \cdot 3 \pm 10 \cdot 2^{* *}$ & $145 \cdot 7 \pm 7 \cdot 6^{* * *}$ \\
\hline \multirow{2}{*}{$\begin{array}{l}\text { Adrenal gland weight } \\
\text { (mg/100 g body weight) }\end{array}$} & Saline & $13 \cdot 7 \pm 0 \cdot 8$ & $15 \cdot 1 \pm 0 \cdot 4$ \\
\hline & Triamcinolone & $9 \cdot 8 \pm 0 \cdot 6^{* *}$ & $9 \cdot 9 \pm 0 \cdot 7^{* * *}$ \\
\hline \multirow{2}{*}{$\begin{array}{l}\text { Thymus weight } \\
\text { (mg/100 g body weight) }\end{array}$} & Saline & $181 \cdot 1 \pm 24 \cdot 2$ & $186 \cdot 4 \pm 30 \cdot 1$ \\
\hline & Triamcinolone & $128 \cdot 3 \pm 16 \cdot 9$ & $132 \cdot 9 \pm 10 \cdot 1$ \\
\hline
\end{tabular}

the microscope. Then, the area of the microscopic field of view and the area of endometrium in transverse section were found by measuring the dimensions of the field of view and the dimensions of the endometrium respectively using an ocular micrometer. The number of stromal cells per section was then calculated. The mitotic index for stromal cells was calculated by dividing the number of mitoses per section into the total number of stromal cells per section. Not less than 10000 stromal cells were analysed per rat.

PCNA- and BrdU-labelling indices for endometrial stromal cells were found in the following way. In a section, the number of labelled cells and the total number of stromal cells per field of view were counted in different regions of the endometrium. At least ten fields of view were analysed per section. The labelling index for stromal cells was calculated by dividing the number of labelled cells into the total number of stromal cells per field of view. Not less than 3000 cells were analysed per animal.

\section{Statistical analysis}

Arithmetic means and standard errors were calculated for each data group. Significance of differences were evaluated by Student's t-test. The significance of the influence of long-term treatment with glucocorticoids at different time points after oestradiol or vehicle injection was determined by two-way ANOVA.

\section{Results}

To assess the general glucocorticoid actions of triamcinolone, body weight and the weight of the adrenal glands and thymus were measured. At $24 \mathrm{~h}$ after treatment with oestradiol or vehicle along with triamcinolone, body weight and the weight of the adrenal glands and thymus were significantly reduced compared with those of control animals treated with saline (Table 1). The data obtained at 36 and $48 \mathrm{~h}$ after injection of oestradiol or vehicle along with triamcinolone were also diminished and did not differ from those obtained at the $24 \mathrm{~h}$ point.

Treatment with oestradiol and saline caused a large increase in the mitotic indices and BrdU- and PCNAlabelling indices of all the uterine structures compared with those of rats not treated with oestradiol. In all the tissues, the values of all parameters continued to increase from 24 to $48 \mathrm{~h}$ after oestradiol injection (Fig. 1).

In the luminal epithelium of the endometrium from animals treated with oestradiol and triamcinolone, the mitotic index and BrdU- and PCNA-labelling indices were decreased at $24 \mathrm{~h}$ (Figs 1 and 2) and $48 \mathrm{~h}$, and increased at $36 \mathrm{~h}$ after oestradiol injection compared with those of rats treated with oestradiol and saline (Fig. 1). Mitotic index and PCNA-labelling index for the glandular epithelium were similar at $24 \mathrm{~h}$ (slightly decreased), increased at $36 \mathrm{~h}$ and decreased at $48 \mathrm{~h}$ compared with control animals treated with oestradiol and saline. BrdUlabelling index for glandular epithelium was higher at $24 \mathrm{~h}$ and lower at 36 and $48 \mathrm{~h}$ than those of control rats (Fig. 1). All differences in the luminal epithelium were statistically significant $(P<0 \cdot 05)$, but those in the glandular epithelium were not so large, especially at 24 and $36 \mathrm{~h}$, and were only statistically significant at $36 \mathrm{~h}$ for the mitotic index and at $48 \mathrm{~h}$ for the BrdU and PCNA-labelling indices (Fig. 1).

Treatment with triamcinolone along with oestradiol led to very interesting changes in the stromal cells, all the parameters of which at all periods were increased compared with control rats treated with oestradiol and saline (Fig. 1). Most changes were observed at the $24 \mathrm{~h}$ time point (Fig. 2). At this point, all differences in mitotic index and BrdU- and PCNA-labelling indices were statistically significant. Results of two-way ANOVA indicate that the influence of long-term treatment with glucocorticoid on proliferative parameters in oestradiol-treated animals is significant only for stromal cells (Table 2).

At $24 \mathrm{~h}$ after treatment with olive oil and saline, mitotic indices and BrdU- and PCNA-labelling indices in all the structures were very low compared with those of animals treated with oestradiol (Fig. 1). The data obtained at 36 and $48 \mathrm{~h}$ after treatment with olive oil and saline did not 
LUMINAL

EPITHELIUM
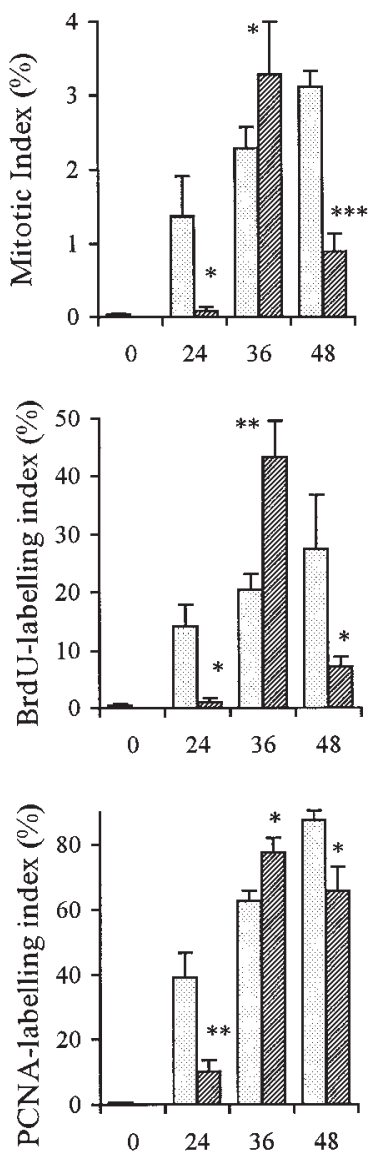

GLANDULAR

EPITHELIUM

STROMA

CELLS
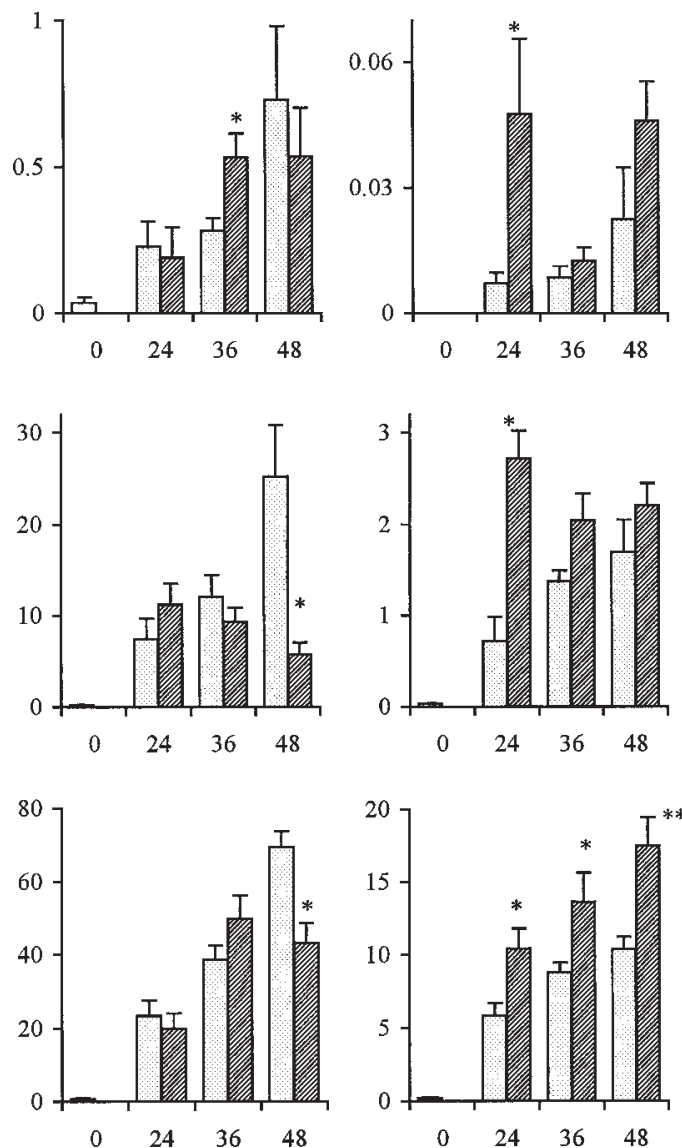

HOURS AFTER OESTRADIOL INUECTION

Figure 1 Effect of long-term treatment with the glucocorticoid triamcinolone on the oestradiol-induced increase in mitotic index, BrdU-labelling index and PCNA-labelling index in the compartments of ovariectomized rat uterus. Data for rats treated with oestradiol and triamcinolone (darkly shaded bars) compared with those of control rats treated with oestradiol and saline (lightly shaded bars) are presented. Crystal triamcinolone acetonide (single dose $0 \cdot 1 \mathrm{mg} / 100 \mathrm{~g}$, i.m.) was injected once a week for 29 days. On the second day after the last triamcinolone administration, the rats were treated with a single injection of oestradiol dipropionate ( $5 \mu \mathrm{g} / 100 \mathrm{~g}$, s.c.) or vehicle (olive oil). At $2 \mathrm{~h}$ before the rats were killed, BrdU (2 mg/100 g i.p.) was given. Measurements were made at 24, 36 and $48 \mathrm{~h}$ after the oestradiol injection. The data at $0 \mathrm{~h}$ are those for rats treated with olive oil and saline $24 \mathrm{~h}$ after the oil injection. No changes were observed in the data of any of the groups not treated with oestradiol. There were seven rats per oestradiol-treated group, and five animals per group not treated with oestradiol. ${ }^{*} P<0 \cdot 05 ;{ }^{* *} P<0 \cdot 01 ;{ }^{* *} P<0 \cdot 001$ compared with the data for rats treated with saline and oestradiol (Student's $t$-test). Values are means \pm S.E.

differ significantly from those obtained at $24 \mathrm{~h}$. In animals treated with olive oil, triamcinolone did not produce any significant changes in any of the parameters tested at any of the time points, compared with those of rats treated with saline. Using two-way ANOVA, no significant effect of triamcinolone was observed in the groups not treated with oestradiol.
In conclusion, long-term treatment with glucocorticoid results in dissimilar changes in oestradiol-induced proliferation of epithelial and connective-tissue (stroma) components of the uterus. In luminal and glandular epithelia, an initial reduction in proliferation at $24 \mathrm{~h}$ is changed to an increase at $36 \mathrm{~h}$ and then a further reduction at $48 \mathrm{~h}$ after oestradiol injection. In stromal cells of the endometrium, 

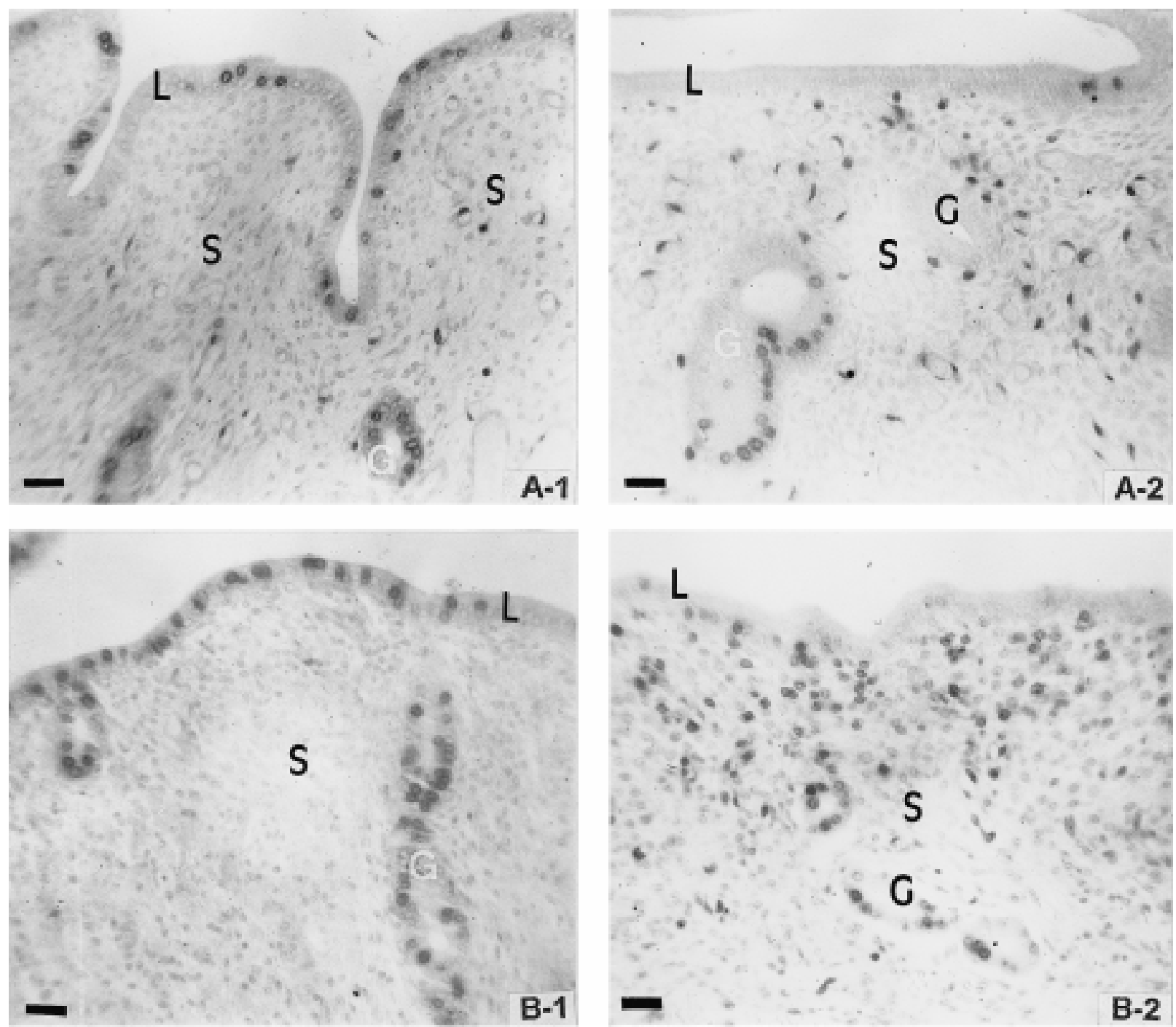

Figure 2 Photomicrographs demonstrating BrdU- (A-1, A-2) and PCNA- (B-1, B-2) labelled cells in the luminal epithelium (L), glandular epithelium (G; white letters) and stromal cells (S) of the endometrium of ovariectomized rats treated with oestradiol and triamcinolone (A-2, B-2) or saline (A-1, B-1), at $24 \mathrm{~h}$ after the oestradiol injection. No staining was observed in the negative control in which normal goat serum was substituted for primary antibodies. Scale bar $20 \mu \mathrm{m}$.

chronic triamcinolone treatment leads to a large constant increase in oestradiol-induced proliferation throughout the experiment. The treatment protocol has no effect on the parameters in the absence of oestradiol administration.

\section{Discussion}

Long-term glucocorticoid treatment was used in these experiments. The effectiveness of the treatment protocol was controlled by analysing well-known general actions of glucocorticoid, such as decreasing body weight and the weight of the thymus and adrenal glands. These par- ameters were measured. Body weight and the weight of the thymus and adrenal glands were significantly reduced after the treatment with triamcinolone. Triamcinolone acetonide was used in crystal form, which produces an increased level of the hormone for more than a week (Mikhail et al. 1977, Lypko et al. 1983). Therefore it can be concluded that the treatment schedule used was appropriate to induce a general chronic hypercorticosteroid effect.

The extent of oestradiol-induced proliferation in the uterus was analysed using three criteria: mitotic index and BrdU- and PCNA-labelling indices. The mitotic index shows how many dividing cells are present in a tissue and 
Table 2 Two-way ANOVA demonstrating the significance of the influence of long-term treatment with triamcinolone on oestradiol-induced effects in the uterus of ovariectomized rats at different time points after oestradiol injection

\begin{tabular}{|c|c|c|c|}
\hline & $\begin{array}{l}\text { Mitotic } \\
\text { index }\end{array}$ & $\begin{array}{l}\text { BrdU-labelling } \\
\text { index }\end{array}$ & $\begin{array}{l}\text { PCNA-labelling } \\
\text { index }\end{array}$ \\
\hline \multicolumn{4}{|l|}{ Uterine structure } \\
\hline Luminal epithelium & NS & NS & NS \\
\hline Glandular epithelium & NS & $P<0.05$ & NS \\
\hline Stromal cells & $P<0.01$ & $P<0.001$ & $P<0.001$ \\
\hline
\end{tabular}

NS, Not significant.

gives information about the M-phase of the cell cycle. $\mathrm{BrdU}$ is incorporated into DNA during the S-phase. Therefore, if BrdU is injected $2 \mathrm{~h}$ before the animals are killed, the BrdU-labelling index shows the number of cells that are in or have just passed through the S-phase. PCNA is an auxiliary protein of DNA polymerase $\delta(36 \mathrm{kDa})$ which is synthesized in late $\mathrm{G}_{1}$ - and S-phases of the cell cycle and is required for DNA synthesis and repair (Woods et al. 1991, Sawtell et al. 1995). PCNA has a half-life of $12 \mathrm{~h}$ and is therefore present in cells that are in the $\mathrm{G}_{1^{-}}, \mathrm{S}_{-}$, $\mathrm{G}_{2^{-}}$and M-phases of the cell cycle (Woods et al. 1991, Sawtell et al. 1995). Thus these three parameters are appropriate for estimating not only the general proliferative activity of a tissue, but also any shifts in the phases of the cell cycle, which are strongly affected by oestrogen hormones. Oestrogens lead to a reduction in the duration of all the stages of the cell cycle and drive cells from the $\mathrm{G}_{0^{-}}$ to the $G_{1}$-phase; this is followed by an increase in the number of cells in and passing through the $\mathrm{G}_{1}$ - and S-phases, as well as the quantity of dividing cells (Quarmby \& Korach 1984, Evans et al. 1990, Galand \& de Maertelaer 1992, Rumpel et al. 1995). Therefore the increase in the mitotic activity and the number of BrdUand PCNA-positive cells in all uterine cell types after oestradiol treatment, observed in the present study, is a direct reflection of these processes.

Treatment with oestradiol and triamcinolone produced an increase in all proliferative parameters at all time points in stromal cells of the endometrium. This indicates that the number of cycling cells in the stroma is increased. In luminal and glandular epithelia, the effect of long-term treatment with triamcinolone is different. The treatment leads to an initial reduction in proliferation at $24 \mathrm{~h}$, followed by a significant increase at $36 \mathrm{~h}$ and a further reduction at $48 \mathrm{~h}$ after oestradiol injection. The decrease in not only the mitotic and BrdU-labelling indices but also the PCNA-labelling index at $24 \mathrm{~h}$ is probably associated with an arrest of the cells in early $G_{1}$-phase, because PCNA begins to be synthesized from the late $G_{1}$-period (Woods et al. 1991, Sawtell et al. 1995). As a result, more cells are accumulated in the early $G_{1}$-phase, which are ready to go on. These cells then begin to drive into the late $G_{1}$-phase and further through the cell cycle, and at
$36 \mathrm{~h}$, this situation is reflected by an increase in the number of PCNA- and BrdU-positive cells as well as the mitotic index. However, at $48 \mathrm{~h}$, all the parameters were again decreased. This is probably associated with these cells being arrested in the next $G_{1}$-phase or with blocking of the entry of these cells into the next cell cycle. Hence, it may be suggested that long-term treatment with triamcinolone leads to an increase in oestradiol-induced proliferative reactions in endometrial stroma and to a decrease in the same in luminal and glandular epithelia, and a key point affected by triamcinolone in epithelial cells is the early $G_{1}$-phase of the cell cycle. It is also shown that no effect of long-term treatment with triamcinolone was observed in the absence of oestradiol. Therefore, it may be proposed that triamcinolone affects the mechanism of oestrogen action on the uterus.

The effect of triamcinolone was probably mediated by glucocorticoid receptors, the presence of which in uterine tissues is well documented (Panko et al. 1981, Giannopoulos et al. 1983). This pathway was confirmed to be the one by which effects of acute treatment with glucocorticoids occur (Campbell 1978, Atkinson \& Adams 1988, Rabin et al. 1990). Acute treatment with glucocorticoids has been shown to greatly diminish oestrogenstimulated proliferative activity as well as the number of oestrogen receptors in all the uterine cell types (Atkinson \& Adams 1988, Rabin et al. 1990, Bigsby 1993). The present work also demonstrates a decrease in proliferation in the luminal and glandular epithelia, where the number of glucocorticoid receptors may also be reduced. However, the effect of long-term treatment with glucocorticoids in stromal cells of the endometrium is different from the effect of short-term treatment. It is possible that the mechanisms involved in the chronic effect of glucocorticoids on stromal cells are also different. Treatment with glucocorticoids for a long time probably leads to a decrease in the number of glucocorticoid receptors in stromal cells. This phenomenon of down-regulation for glucocorticoid receptors has been shown in different target tissues after long-term treatment with glucocorticoids (Schmidt \& Meyer 1994, Herman et al. 1995, Sapolsky 1996). Interestingly, prolonged administration of oestrogen steroids also leads to a decrease in the number of oestrogen 
receptors in the uterus (Mukku et al. 1982, Medlock et al. 1991).

It cannot be excluded that progesterone receptors are involved in the action of triamcinolone. Progesterone has been documented to stimulate oestradiol-dependent proliferation of stromal cells (Martin \& Finn 1969, Finn et al. 1995) and to diminish this process in uterine epithelium, where it affects the $G_{1}$-phase of the cell cycle and blocks the entry of epithelial cells into a second round of DNA synthesis (Das \& Martin 1973, Martin et al. 1973). The present results are similar, and it is possible that the effect of triamcinolone on the uterus is achieved through progesterone receptors. Moreover, cross-reactivity between glucocorticoid and progesterone receptors has been documented (Panko et al. 1981, Von der Ahe et al. 1985).

Another possible pathway may involve prolactin. It is known that long-term treatment with glucocorticoids can lead to a decrease in prolactin concentration (Piroli et al. 1993, Taylor et al. 1995), and prolactin has been shown to reduce oestradiol-induced proliferation in the uterus (Gunin 1996). Therefore the effect of triamcinolone, at least on stromal cells, may be mediated through a decrease in the level of prolactin.

So, the mechanisms involved in the observed effect remain unclear, and further experiments are needed to define it. In conclusion, it should be noted that this is the first report that demonstrates not only the effect of long-term glucocorticoid action on the uterine response to oestradiol but also a large increase in oestrogen-induced proliferation in the uterus after the administration of glucocorticoids. We hope that these data will lead to a deeper understanding of the origin and development of oestrogen-dependent cancer of the female reproductive system.

\section{References}

Atkinson S \& Adams NR 1988 Adrenal glands alter the concentration of oestradiol-17 beta and its receptor in the uterus of ovariectomized ewes. Journal of Endocrinology 118 375-380.

Bigsby RM 1993 Progesterone and dexamethasone inhibition of estrogen-induced synthesis of DNA and complement in rat uterine epithelium: effects of antiprogesterone compounds. Jourrnal of Steroid Biochemistry and Molecular Biology 45 295-301.

Campbell PS 1978 The mechanism of the inhibition of uterotrophic responses by acute dexamethasone pretreatment. Endocrinology 103 716-723.

Das RM \& Martin L 1973 Progesterone inhibition of mouse uterine epithelial proliferation. Journal of Endocrinology 59 205-206.

Dey SK, Hoversland RC \& Johnson DC 1982 Phospholipase A2 activity in the rat uterus: modulation by steroid hormones. Prostaglandins 23 619-630.

Evans G, Gibson DFC, Roberts SA, Hind TM \& Potten CS 1990 Proliferative changes in the genital tissue of female mice during the oestrous cycle. Cell and Tissue Kinetics 23 619-635.

Finn CA, Pope M \& Milligan SR 1995 Control of uterine stromal mitosis in relation to uterine sensitivity and decidualization in mice. Journal of Reproduction and Fertility 103 153-158.

Galand P \& de Maertelaer V 1992 Models of oestrogen action: a cell kineticist's view. Epithelial Cell Biology 1 177-188.
Giannopoulos G, Jackson K \& Tulchinsky D 1983 Specific glucocorticoid binding in human uterine tissues, placenta and fetal membranes. Journal of Steroid Biochemistry 19 1375-1378.

Gunin A 1996 The role of prolactin in realization of estradiol action in the uterus of ovariectomized rats. European Journal of Obstetrics and Gynecology and Reproductive Biology 64 119-127.

Herman JP, Adams D \& Prewitt C 1995 Regulatory changes in neuroendocrine stress-integrative circuitry produced by a variable stress paradigm. Neuroendocrinology 61 180-190.

Jacobs AL, Hwang D, Julian J \& Carson DD 1994 Regulated expression of prostaglandin endoperoxide synthase- 2 by uterine stroma. Endocrinology 135 1807-1815.

Kirkland JL, Murthy L \& Stancel GM 1992 Progesterone inhibits the estrogen-induced expression of c-fos messenger ribonucleic acid in the uterus. Endocrinology 130 3223-3230.

Lacey A, Ed 1989 Light Microscopy in Biology: A Practical Approach. Oxford: IPR Press at Oxford University Press.

Lippe BM \& Szego CM 1965 Participation of adrenocortical hyperactivity in the suppressive effect of systemic actinomycin D on uterine stimulation by oestrogen. Nature 207 272-274.

Lisk RD \& Reuter LA 1976 Dexamethasone: increased weights and decreased $\left[{ }^{3} \mathrm{H}\right]$ estradiol retention of uterus, vagina and pituitary in the ovariectomized rat. Endocrinology 99 1063-1070.

Lypko A, Lazowski J, Szczudlik A \& Wasek Z 1983 The depot-form of glucocorticoid decreases cortisol but not ACTH and beta-endorphin levels in human plasma. Hormone and Metabolic Research 15 104-106.

Markaverich BM, Upchurch S \& Clark JH 1981 Progesterone and dexamethasone antagonism of uterine growth: a role for a second nuclear binding site for estradiol in estrogen action. Journal of Steroid Biochemistry 14 125-132.

Martin L \& Finn CA 1969 Duration of progesterone treatment required for a stromal response to oestradiol-17-beta in the uterus of the mouse. Journal of Endocrinology 44 279-280.

Martin L, Das RM \& Finn CA 1973 The inhibition by progesterone of uterine epithelial proliferation in the mouse. Journal of Endocrinology 57 549-554.

Medlock KL, Lyttle CR, Kelepouris N, Newman ED \& Sheehan DM 1991 Estradiol down-regulation of the rat uterine estrogen receptor. Proceedings of the Society for Experimental Biology and Medicine 196 293-300.

Mikhail G, Sweet L \& Mellinger R 1977 Long-term intramuscular administration of triamcinolone acetonide. Archives of Dermatology 113 111-114.

Monheit AG \& Resnik R 1981 Corticosteroid suppression of estrogen-induced uterine blood flow in nonpregnant sheep. American Journal of Obstetrics and Gynecology 139 454-458.

Mukku VR, Kirkland JL, Hardy M \& Stancel GM 1982 Hormonal control of uterine growth: temporal relationships between estrogen administration and deoxyribonucleic acid synthesis. Endocrinology $111480-487$.

Nagaoka T, Takeuchi M, Onodera H, Mitsumori K, Lu J \& Maekawa A 1993 Experimental induction of uterine adenocarcinoma in rats by estrogen and N-methyl-N-nitrosourea. In Vivo 7 525-530.

Pakrasi PL, Cheng HC \& Dey SK 1983 Prostaglandins in the uterus: modulation by steroid hormones. Prostaglandins 26 991-1009.

Panko WB, Clark JH \& Walters MR 1981 Glucocorticoid receptors: documentation in the rat uterus. Journal of Receptor Research 2 29-45.

Piroli G, Grillo C, Ferrini M, Diaz Torga G, Libertun C \& De Nicola AF 1993 Restoration by bromocriptine of glucocorticoid receptors and glucocorticoid negative feedback on prolactin secretion in estrogen-induced pituitary tumors. Neuroendocrinology $\mathbf{5 8}$ 273-279.

Pottinger TG 1990 The effect of stress and exogenous cortisol on receptor-like binding of cortisol in the liver of rainbow trout, Oncorhynchus mykiss. General and Comparative Endocrinology 78 194-203. 
Quarmby VE \& Korach KS 1984 The influence of 17beta-estradiol on patterns of cell division in the uterus. Endocrinology 114 694-702.

Rabin DS, Johnson EO, Brandon DD, Liapi C \& Chrousos GP 1990 Glucocorticoids inhibit estradiol-mediated uterine growth: possible role of the uterine estradiol receptor. Biology of Reproduction $\mathbf{4 2}$ 74-80.

Rumpel E, Michna H \& Kuhnel W 1995 PCNA-immunoreactivity in the uterus of rats after treatment with the antiestrogen tamoxifen. Anatomisher Anzeiger 177 133-138.

Sahlin L 1995 Dexamethasone attenuates the estradiol-induced increase of IGF-I mRNA in the rat uterus. Journal of Steroid Biochemistry and Molecular Biology 55 9-15.

Sapolsky RM 1996 Stress, glucocorticoids, and damage to the nervous system: the current state of confusion. Stress 1 1-19.

Sawtell RM, Rew DA, Stradling RN \& Wilson GD 1995 Pan cycle expression of proliferating cell nuclear antigen in human colorectal cancer and its proliferative correlations. Cytometry 22 190-199.

Schmidt TJ \& Meyer AS 1994 Autoregulation of corticosteroid receptors. How, when, where, and why? Receptor 4 229-257.

Stewart PJ, Zaloudek CJ, Inman MM \& Webster RA 1983 Effects of dexamethasone and indomethacin on estrogen-induced uterine growth. Life Sciences 33 2349-2356.

Sullivan DA, Underdown BJ \& Wira CR 1983 Steroid hormone regulation of free secretory component in the rat uterus. Immunology 49 379-386.
Taylor A, Cowell A, Flower R \& Buckingham J 1995 Dexamethasone suppresses the release of prolactin from the rat anterior pituitary gland by lipocortin 1 dependent and independent mechanisms. Neuroendocrinology $62530-542$.

Tchernitchin A, Rooryck J, Tchernitchin X, Vandenhende J \& Galand P 1975 Effects of cortisol on uterine eosinophilia and other oestrogenic responses. Molecuular and Cellular Endocrinology 2 331-337.

Von der Ahe D, Janich S, Scheidereit C, Renkawitz R, Schutz G \& Beato M 1985 Glucocorticoid and progesterone receptors bind to the same sites in two hormonally regulated promoters. Nature $\mathbf{3 1 3}$ 706-709.

Woods AL, Hall PA, Shepherd NA, Hanby AM, Waseem NH, Lane DP \& Levison DA 1991 The assessment of proliferating cell nuclear antigen (PCNA) immunostaining in primary gastrointestinal lymphomas and its relationship to histological grade, $\mathrm{S}+\mathrm{G}_{2}+\mathrm{M}$ phase fraction (flow cytometric analysis) and prognosis. Histopathology 19 21-27.

Zamorano P, Steinsapir J \& Mahesh VB 1992 Effect of 5 alphadihydrotestosterone and dexamethasone on estrogen receptors of the anterior pituitary and uterus. Steroids 57 18-26.

Received 2 June 1997

Revised manuscript received 22 September 1997 Accepted 16 February 1998 